teins in normal and lipoprotein lipase-deficient humans. Proc Natl Acad Sci USA 81: 1839-1843

2. Haffner SM, Foster DM, Kushwaha RS, Hazard WR (1984) Retarded chylomicron apolipoprotein-B catabolism in Type 2 (non-insulin-dependent) diabetic subjects with lipaemia. Diabetologia 26 : 349-354

3. Phair RD, Hall M III, Bilheimer DW, Levy RI, Goebel RH, Berman M (1976) Modeling lipoprotein metabolism in man. In: Proceedings of the Summer Computer Simulation Conference, Washington, DC, July 1976. California Simulation Councils, San Diego, California, pp 486-492

4. Berman M, Weiss MF (1967) SAAM Manual. US Public Health Service Publication No.1703. US Government Printing Office, Washington, DC

5. Haffner S, Kushwaha R, Foster D, Hazzard WR (1980) Catabolism of chylomicron apo-B in normal and diabetic subjects. Circulation 62 (Suppl III): 195 (Abstract)

Dr. Rampratap S. Kushwaha

Southwest Foundation for Biomedical Research

West Loop 410 at Military Drive

PO Box 28147

San Antonio

Texas 78274

USA

\section{Hyperinsulinism in iron overload}

Dear Sir

Niederau et al. have demonstrated hyperinsulinism in association with normal glucose tolerance in pre-cirrhotic patients with haemochromatosis [1]. Almost identical observations and conclusions were obtained by us in 15 younger patients with transfusional iron overload, five of whom had cirrhosis and nine had severe hepatic fibrosis [2]. Oral glucose tolerance tests showed plasma glucose concentrations. which were within the normal range in all patients except one, who had 'frank' diabetes. There was, however, a unique pattern of a secondary rise of glucose concentrations at $120 \mathrm{~min}$ in seven of these patients, all of whom had glucose tolerance curves within the normal range. Thus, the $120 \mathrm{~min}$ glucose concentrations $(5.9 \pm 0.3 \mathrm{mmol} / \mathrm{l})$ were significantly higher $(p<0.02)$ than those at $90 \mathrm{~min}(4.7 \pm 0.2)$, whilst the latter were lower $(p<0.01)$ than the peak concentrations achieved at $30 \mathrm{~min}(6.2 \pm 0.5 \mathrm{mmol} / \mathrm{l})$. Such a pattern is not recognised

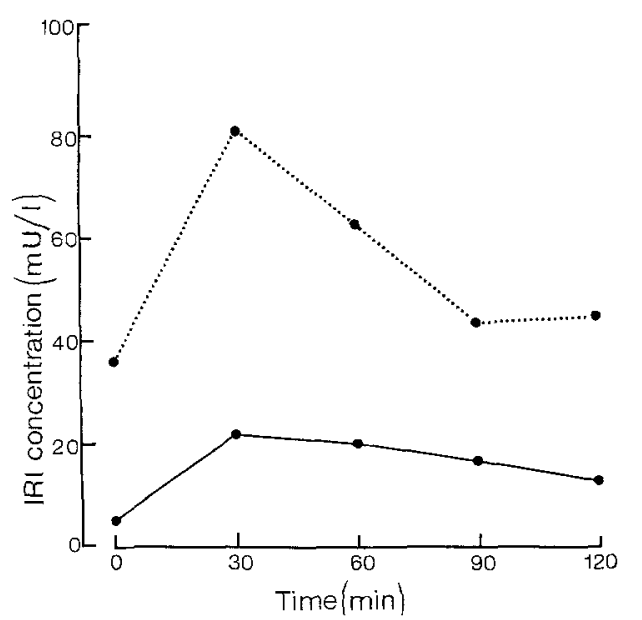

Fig. 1. The median IRI concentrations in patients with iron overload (-...) and control subjects (--) following a glucose challenge. Ranges of IRI concentrations ( $\mathrm{mU} / 1)$ : control subjects: $0 \mathrm{~min}$ : $0-10$; $30 \mathrm{~min}: 12-38 ; 60 \mathrm{~min}: 13-39 ; 90 \mathrm{~min}: 30-72 ; 120 \mathrm{~min}: 3-23$. Patients: $0 \mathrm{~min}: 18-44 ; 30 \mathrm{~min}: 38-116 ; 60 \mathrm{~min}: 35-101 ; 90 \mathrm{~min}$ : $30-72 ; 120 \mathrm{~min}: 30-80$. The difference between the two curves was statistically significant at all points of measurement $(p<0.01)$ or associated with any condition. Fasting immunoreactive insulin (IRI) concentration was greater than $20 \mathrm{mU} / 1$ (age- and sex-matched control subjects: $10 \mathrm{mU} / 1$ ) in all patients except two, one of whom had diabetes. The response of IRI to glucose was markedly greater than that seen in control subjects (Fig. 1).

These data are directly comparable to those presented by Niederau et al. [1]. The presence of fasting and post-glucose hyperinsulinism suggests the presence of insulin resistance as the initial abnormality of glucose metabolism following iron overload. This is caused by inadequate insulin extraction by the liver. The development of diabetes probably follows a relative decompensation of the pancreatic $\beta$-cell due to continuing iron overload and injury of the pancreas. It is of interest that the only patient in our series, who had diabetes, had a fasting IRI concentration greater than that in control subjects but less than that in non-diabetic patients with iron overload. It is also of relevance that in patients with iron overload, the development of cirrhosis is not necessarily associated with a significant further abnormality of glucose metabolism, since cirrhotic patients showed glucose tolerance and IRI response not significantly different from those seen in patients without cirrhosis. Thus, pancreatic iron overload with $\beta$-cell destruction and not cirrhosis is the final crucial step in the pathogenesis of diabetes due to iron overload.

Since there is increasing evidence that there is an abnormality of exocrine pancreatic function in diabetes [3-6], we have also investigated the presence of an exocrine pancreatic deficit caused by iron overload. There has hitherto been no evidence to show exocrine pancreatic deficit due to iron overload in such patients ante mortem. Using recently developed assay techniques, we were able to show that serum immunoreactive trypsin concentrations and pancreatic lipase activity are markedly lower in patients with iron overload and are comparable with those found in diabetes $[7,8]$ and severe chronic pancreatitis [9]. It is of interest, however, that neither diabetic patients nor patients with iron overload have pancreatic steatorrhoea.

Yours sincerely,

P. Dandona, D. M. Flynn and A. V. Hoffbrand

\section{References}

1. Niederau C, Berger M, Stremmel W, Starke A, Strohmeyer G, Ebert R, Siegel E, Creutzfeldt W (1984) Hyperinsulinaemia in non-cirrhotic haemochromatosis: impaired insulin degradation. Diabetologia 26: 441-444

2. Dandona P, Hussein MAM, Varghese Z, Politis D, Flynn DM, Hoffbrand AV (1983) Insulin resistance and iron overload. Ann Clin Biochem 20:77-79

3. Frier BM, Saunders JHB, Wormley KG, Bouchier IAD (1976) Exocrine pancreatic function in diabetes mellitus. Gut 17:685-689

4. Dandona P, Elias E, Beckett AG (1978) Serum trypsin in diabetes mellitus. Br Med J II: 1125-1126

5. Dandona P, Freedman DB, Foo Y, Perkins JR, Katrak A, Mikhailidis DP, Rosalki SB, Beckett AG (1984) Exocrine pancreatic function in diabetes mellitus. J Clin Pathol 37: 302-306

6. Junglee D, de Albarran R, Katrak A, Beckett AG, Dandona P (1983) Serum pancreatic lipase activity in diabetes mellitus. J Clin Pathol 36: 200-202

7. Hussein MAM, Dandona P, Fedail M, Flynn DM, Hoffbrand AV (1981) Serum immunoreactive trypsin in $\beta$-thalassaemia major. $\mathbf{J}$ Clin Pathol 34: 970-971

8. Junglee D, Katrak A, Hoffbrand AV, Dandona P (1983) Serum pancreatic lipase activity in $\beta$-thalassaemia major. Clin Chem 29 : 2003-2004

9. Elias E, Redshaw M, Wood T (1977) Diagnostic importance of changes in circulating concentration of immunoreactive trypsin. Lancet 2: 66-68

Dr. P.Dandona

Metabolic Unit

Department of Chemical Pathology and Human Metabolism

Royal Free Hospital

Pond Street

London NW3 2QG, UK 